\title{
Inclusive Practicum: Creating Networks of Learning and Collaboration between Students, Teachers, and the Faculty of Education
}

Datos de contacto:

Yolanda Muñoz Martínez Universidad de Alcalá Facultad de Educación yolanda.munozm@uah.es

Susana Domínguez Santos Universidad de Alcalá Facultad de Educación susana.dominguez@uah.es

Slavka Madarova Universidad de Alcalá Filología Moderna s.madarova@uah.es

Silvia de la Sen Pumares Universidad de Alcalá Facultad de Educación silvia.sen@uah.es

Jesús García Laborda Universidad de Alcalá Facultad de Educación jesus.garcialaborda@uah.es

Recibido: 24/04/2021 Aceptado: 02/11/2021

\author{
Yolanda MUÑOZ MARTÍNEZ \\ Susana DOMÍNGUEZ SANTOS \\ Slavka MADAROVA \\ Silvia DE LA SEN PUMARES \\ Jesús GARCÍA LABORDA
}

\begin{abstract}
The presented Teaching Innovation project deals with establishment of support, learning and collaboration networks between university and non-university teaching staff. This was done with two fundamental purposes in mind: on the one hand, improving the training of Practicum students through joint reflection and, on the other hand, promoting inclusive education in schools through support networks among teachers. Participants were the Practicum students from the Faculty of Education, specifically students with the major in Special Educational Needs. The project included creation of joint seminars between Practicum tutors of the Faculty, tutors from schools and Practicum students. Moreover, initiating support networks allowed involving two different schools in two Autonomous Communities, which has been a highly enriching experience for all participants.
\end{abstract}

KEYWORDS: practicum; inclusive education; collaboration networks; innovation. 


\section{Prácticum Inclusivo: Creando redes de aprendizaje y colaboración entre los estudiantes, los maestros y la Facultad de Educación}

\section{RESUMEN}

El proyecto de Innovación Docente presentado trata sobre el establecimiento de redes de apoyo, aprendizaje y colaboración entre el profesorado universitario y no universitario. Esto se hizo con dos propósitos fundamentales en mente: por un lado, mejorar la formación de los estudiantes de Prácticum a través de la reflexión conjunta $\mathrm{y}$, por otro lado, promover la educación inclusiva en las escuelas a través de redes de apoyo entre docentes. Los participantes fueron los estudiantes de Prácticum de la Facultad de Educación, específicamente estudiantes con mención de Necesidades Educativas Especiales. El proyecto incluyó la creación de seminarios conjuntos entre tutores de Prácticum de la Facultad, tutores de centros educativos y alumnos de Prácticum. Además, la puesta en marcha de redes de apoyo permitió involucrar a dos centros educativos diferentes en dos Comunidades Autónomas, lo que ha sido una experiencia muy enriquecedora para todos los participantes.

PALABRAS CLAVE: prácticum; educación inclusiva; redes de colaboración; innovación.

\section{Introductión}

Various investigations show that the Practicum is one of the crucial moments for the development of professional competences in students (Esposito et al., 2015; Guiney, 2018; García-Martínez et al., 2019; Pérez, 2019; Mérida, 2001; Fernández et al., 2001; Zabalza, 2003; Pérez \& Gallego, 2004, Villa \& Poblete, 2004, Smith \& Lev-Ari, 2005; Pérez, 2012). However, the evidence found in the literature suggests that there are still important shortcomings in the procedures that guide the learning carried out in this period (Knapczyk et al., 2005), as well as the relationships between the Faculties of Education and the schools (Beck \& Kosnik, 2002; Grudnoff et al., 2017; Huong et al., 2020) that implement these practices; sometimes even due to the identification of the roles of the university mentor and the school teacher (Burns et al., 2016; Mauri et al., 2019). This leads to separation between theory and practice (Turunen \& Tuovila, 2012; Schuijers et al., 2013; Allen \& Wright, 2014; Stenberg et al., 2016), in many cases perpetuated from initial training up to the professional development of the teacher (Mukeredzi, 2015; Ulvik, Helleve et al., 2018; Widdall et al., 2019). Moreover, it entails a break in the logic of practice based on evidence and research results. As stated by Mérida et al. (2012), 
the Practicum is a privileged space to articulate the relationships between schools and the university. It acts as a 'hinge' period in which theoretical and practical training converge, and its development pivots on the collaboration of professionals belonging to two different institutions (p. 49, own translation).

For this reason, it is in the Practicum where the inter-institutional relationship, the status, role and conception, in one word, one's identity is developed (Seban, 2015; Trent, 2013, 2018; Prabjandee, 2019; Yuan et al., 2019). The traditional concept of the relationship between school and university is based first, on the active practical knowledge, and second, on the theoretical knowledge that generates practicing teacher's own research (Mérida et al., 2012; Parr \& Chan, 2015) and it is the contrast between theory and practice with an emotional personal implication what actually promotes the personal growth (Williams, 2014; Nguyen, 2017; Zhu, 2017) through a reflective process (Köksal \& Genç, 2019).

This teaching innovation project is based on the idea that the Practicum is a space for learning by dialectically (Illin, 2020; Tan et al., 2020) contrasting theory and practice. It presupposes the immersion of the student in a real professional context, joining as an apprentice who has to observe, interpret, make decisions and reflect on various areas of educational reality (Mérida et al., 2012, p. 448). Moreover, our proposal is to approach this necessary approximation between theory and practice jointly with practicing teachers. We understand, as stated by Ruiz-Bernardo, SánchezTarazaga \& Mateu-Pérez (2018), that "action-research is a form of self-reflective and co-reflective inquiry undertaken by a group of people who share concerns and interests and seek to resolve or improve problematic situations in their daily lives" (p. 35, own translation). This is the case of the Practicum in the Degree in Primary Education with the major in Special Educational Needs (Conroy, 2014), through a participatory inquiry strategy that includes all the voices involved (Sales et al., 2012; Méndez \& Pérez, 2017).

To us, "a smart school" or a school in the process of becoming one, cannot look only at reflective student learning, but must be a contextualized and dynamic environment that also provides ground for self-reflection to the teachers. The figure of the reflective practitioner is at the centre of the occupation pursuit, at least when we consider it from the point of view of experience, intelligence at work and professional autonomy; or in the words of Dewey (1989), "the function of reflective thought (...) is to transform a situation in which darkness, doubt, conflict or some type of disturbance is experienced, into a clear, stable and harmonious situation" (p. 98, own translation).

To move towards a true reflective practice, this position needs to become something almost permanent in teaching and classroom management (Ragawanti, 2015; Han et al., 2020). It should be inscribed within an analytical relationship with the action that becomes something relatively independent of the possible obstacles or disappointments. This is closely related to the objective of action research, which according to Elliot (1990) consists in deepening the teachers' understanding (diagnosis) of their problem. Therefore, the teacher adopts an exploratory stance in the face of whatever initial definitions of their own situation they may maintain (p. 5, own translation). We agree with Nieves Blanco García (2005, p. 379) that there is a need for concepts and research strategies appropriate for the characteristics of the 
knowledge linked to experience thus requiring that we approach them respecting said quality instead of eliminating it. Therefore, we are defending the figure of the teacher who investigates, enquires about their practice, explores the relationship with what happens in the classroom, who has the need to delve into action in order to improve it. As López Melero (2004, p. 268) rightly says, only when the need for improvement and collaboration floods the thinking of the teaching staff - then and not before - the responsible institutions will have to create strategies for the development of the teaching staff involved in this new culture.

The figure of the reflective practitioner and related reflections on education were known long ago (Tiainen et al., 2018). The great pedagogues, each in their own way, have considered teachers as inventors, researchers, craftsmen, adventurers who dare to move away from the traced paths and who would be lost if it were not for reflecting intensely on their own acts and learning quickly from their own experience. Schön (1998) conceptualizes more explicitly the figure of the reflective practitioner, proposing an epistemology of practice, reflection and knowledge in action. We must consider the collective analysis of practice as an initiation to reflective practice, through focus groups with members of the educational community. When the analysis of practice has as its objective the transformation of people, their attitudes and their actions, it requires from each one a true work on themselves. It calls for time and effort, exposes us to the gaze of others, invites us to question everything and can be accompanied by a crisis or a change of self-identity from teacher-student to practitioner teacher. As Ainscow (2001, p. 55) explains, change, especially when it involves new ways of thinking and behaving, is a difficult and slow process.

Therefore, we must favour the improvement processes in the school, stimulate its institutionalization and promote committed, self-critical and responsible situations of self-review of professional and institutional action, of analysis of its pedagogical practice, of implicit education that could be involved. developing in it, of the consequences of this in their students, in their personal and social development, and of consideration of the didactic, ethical and ideological principles that underpin all this practice. We would therefore be talking about action-research processes (Ulvik, 2014; Kasula, 2015; Robinson \& Walters, 2016; Ulvik, Riese et al., 2018) particularly in special education (Conroy, 2014). As Kemmis and McTaggart (1988) well define it, it would be a form of collective introspective inquiry undertaken by participants in social situations in order to improve the rationality and justice of their social or educational practices, as well as their understanding of these practices and the situations in which they take place.

As Freire (1990) explained, consciousness is not transformed through courses and speeches, or eloquent sermons, but by the action of human beings on the world. It implies a conjunction between theory and practice in which both are being constituted, becoming a permanent movement from practice to theory and from this to a new practice. Each member of a focus group internalizes during the meetings positions and methods of analysis that can be taken away from the collective procedure and from any device to be framed, their class, their centre or their life. A focus group has the objective of helping to develop in each one a capacity for analysis and, possibly, strategies for personal change. The analysis of complex situations and the behaviours that they 
favour often cause certain training needs to emerge; it pushes the practitioners involved to build their own balance of competencies, which can lead them, if necessary, to the decision to get better training. For those who choose this proposal freely and with knowledge of the facts, the most defensible reason is undoubtedly the will to face a doubt, discomfort or search that leads to wonder about the practice and what supports it.

Thus, this project aims to promote the joint reflection of schoolteachers and education students through the privileged space of the Practicum and create a facilitating context such as the joint seminars hereby presented. Establishing support networks between university and non-university teachers for the training of future teachers is an essential element for the improvement of the afore mentioned training and also offers possibilities for school improvement through the participation of internship students (Sim, 2010; Álvarez \& Osoro, 2014). In this line, it is the project presented here, which may constitute the basis for collaborative processes, and could generate a symbiosis between the participant university and the involved schools, as well as some dynamics to improve pre-service teachers training through the Practicum.

\section{Inclusive education}

When addressing inclusive Education, it is a school restructuring process, or better said, the implementation of innovation and improvement processes that bring schools closer to the objective of promoting the presence, participation and performance of all students from the field of Education. This includes those vulnerable to exclusion processes, thus learning to live with the difference and to improve thanks to those exact differences among the students (Echeita, 2008). The core purpose is leaving the school system, particularly in the compulsory stage, with a fair and sufficient training background.

Inclusive education can be conceived as a process that addresses and responds to the diverse needs of all learners through greater participation in learning, cultural and community activities and by reducing exclusion within and outside the educational system. The foregoing implies changes and modifications of contents, approaches, structures and strategies. These are based on a common vision that encompasses all school-age children and the conviction that it is the responsibility of the ordinary educational system to educate all children. This implies a break with certain practices and policies that have been happening in Spain, and that have to do with specialization in Special Needs, and the belief that each individual child should be assisted by a in special needs education with relevant knowledge.

The goal of inclusion is to provide appropriate responses to the broad spectrum of learning needs in both formal and non-formal educational settings. Inclusive education is more than a marginal topic that deals with how to integrate certain students into mainstream education. It represents a perspective that should serve to analyse how to transform education systems and other learning environments to respond to the diversity of the students (Lupart \& Webber, 2012; Magumise \& Sefotho, 2020). 
Therefore, we would not be talking about special education, or special educational needs. We would be talking about school improvement from the perspective of quality education for all children, achievements for all, not only for those who are considered "normal".

To speak of equal opportunities and equity is to speak of the need for an education for all children without exceptions. It's an education without "buts", a quality education that leads all students towards their full potential and allows them having access to a dignified life, preventing them from being victims of social exclusion. This is the objective of the major in Special Educational Needs, to train teachers who are capable of making education fairer, increasing its quality while respecting the differences of students, focusing on those strategies that make it possible for all to advance and develop, both academically and socially.

\section{Schools with inclusive practices}

It is especially important for this advance to happen together with the advance of schools. Both should work on the design and development of methodologies and strategies to respond to the needs of all students in the framework of the ordinary classroom. This project aims to put its grain of sand to make this happen. To this end, we created a network of centres with inclusive practices, which already guarantee us in advance that the environment in which students will complete their Practicum offers educational models consistent with the theoretical teachings that are being carried out in the major in Special Educational Needs (with emphasis on inclusive education). We hope that this network of centres with inclusive practices will grow every year. Participating centres with their characteristics are detailed next:

\section{Table 1}

Participating centres

\begin{tabular}{|c|c|}
\hline Centre & Characteristics \\
\hline $\begin{array}{l}\text { The La Paloma Public } \\
\text { School in Azuqueca de } \\
\text { Henares } \\
\text { (CEIP La Paloma de } \\
\text { Azuqueca de Henares) }\end{array}$ & 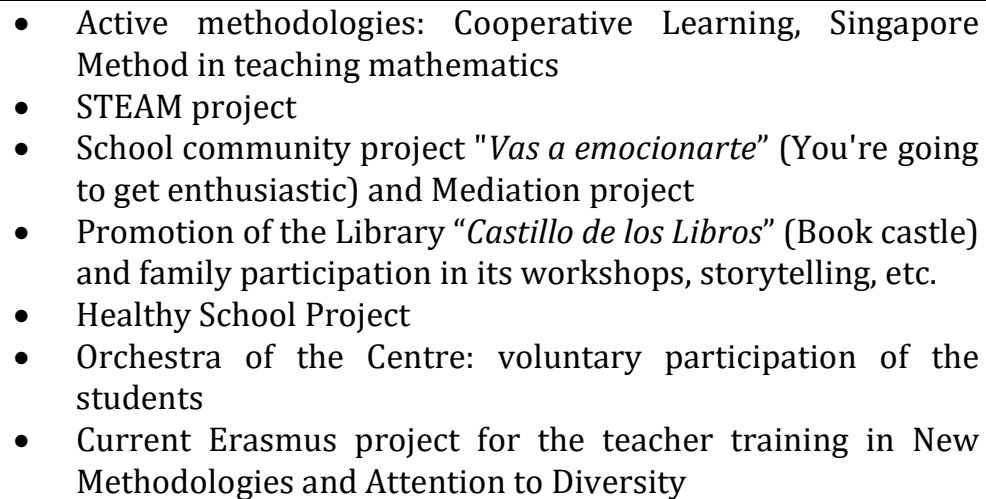 \\
\hline
\end{tabular}




\begin{tabular}{|c|c|}
\hline & - $\quad$ National School Libraries Award, $2008^{1}$ \\
\hline $\begin{array}{l}\text { The San Sebastián de } \\
\text { Meco Public School } \\
\text { (CEIP San Sebastián de } \\
\text { Meco) }\end{array}$ & $\begin{array}{l}\text { - Educational project of a centre based on Cooperative learning } \\
\text { and teaching. The centre has been training all its teachers for } \\
\text { more than } 4 \text { years and creating collaboration strategies } \\
\text { among its teachers (cooperative teachers' assembly). This } \\
\text { was done so that all teachers at the centre use Cooperative } \\
\text { learning as a basic educational approach, as reflected in its } \\
\text { Educational Project (PEC) and in the usual classroom } \\
\text { dynamics. } \\
\text { - Mathematics through active methods } \\
\text { - Finalists of } 2018 \text { "Convive Comunidad de Madrid" awards, for } \\
\text { their School Community Project } \\
\text { Winner of the I Prize "Vitamina Educativa" (Educational } \\
\text { Vitamin) } 2017 \text { for innovation in Cooperative Learning and } \\
\text { School community Coexistence in the category of Cooperative } \\
\text { Learning Experiences. }\end{array}$ \\
\hline
\end{tabular}

\section{Method}

The presented case study was carried out during the 2019-20 academic year with the participation of seven teachers from two Primary schools, two directors from the two schools involved, four Practicum students, as well as two university professors. Three discussion groups of more than 2 hours duration each were held with all the participants. Their purpose was the analysis of and reflection on the methodologies and strategies that were implemented in the classrooms and that favoured participation, learning and sense of belonging for all students.

An ad hoc questionnaire was designed to analyse the results of the project. The questionnaire consisted of two versions, one for teachers and one for students with a total of nine questions. It was designed around the following dimensions related to the theoretical review of the study: teacher training, teaching innovation and relationship between the university and the school. At the end of the project, the questionnaire was passed online to all participants. In total, we obtained four responses from the students, which is $100 \%$, and four responses out of a total of six from the Practicum teachers from the schools.

\section{Participants}

The participants were teachers from two public schools of early childhood and primary education (students from 3 to 12 years old) located in two different regions, Madrid and Castilla-La Mancha (Guadalajara) as well as university students who carried out their internship in those schools and two teachers' university students who also acted as facilitators of the discussion groups. A total of 9 teachers, 5 university

1 (To learn more, please see the documentary "yo aprendo - tu aprendes" (I learn - You learn) at https://www.cmmplay.es/conocimiento/yo-aprendo-tu-aprendes/ceip-la-paloma-azuqueca-dehenares_v) 
students and 2 research lecturers took part in the project.

Two schools from two different provinces that have participated in this innovation project during the academic year both implemented inclusive practices in teaching. The schools and their characteristics are as follows:

The La Paloma Public School in Azuqueca de Henares, in the province of Guadalajara. This school welcomes children from 3 to 12 years old and has more than 700 students. Diversity is present in the school since all the schools in this province can admit children with special needs. The school implements many projects and methodologies to give a better response to all students. The main ones are the following: Active methodologies - Cooperative learning, Singapore Method in teaching mathematics, STEAM Project for scientific skills, project to improve the school community "Te vas a emocionar" (You are going to get enthusiastic). They also encourage the participation of families through the school library in which families prepare workshops, tell stories, etc.

The San Sebastián de Meco Public School, province of Madrid. This school also welcomes children from 3 to 11 years old and has more than 600 students. Diversity is present in the school since all the schools in this province can admit children with diverse needs and characteristics. The school has been training all its teachers for more than 5 years. It created collaborative strategies among its teachers so that all use Cooperative Learning as a basic educational approach. This is reflected in its Educational Project (PEC) and in the usual classroom dynamics. Moreover, the school teaches Mathematics through active methods and uses a specific project for school community, including peaceful conflict resolution through emotional education.

\section{Data Collection}

Data was collected through the videorecording of the three discussion groups and the documentary analysis of the final written report of each student. The three videos were transcribed and transcriptions were analysed. 5 reflective works (final written reports) about the students' practice period were analysed.

Qualitative analysis software Nvivo was used for data analysis, which facilitated the handling of a significant amount of information.

\section{Procedure}

The initial education of teachers, especially with regard to inclusive education, tends to focus on the theoretical training received at the University. In many cases it has little connection with what the students later see / apply during their Practicum in the schools. This project understands that inclusive education is the responsibility of the entire educational community, including students in Practicum. Hence, the focus is placed on their stay in schools as a way to establish a network between the university and schools to create spaces for joint reflection with the aim of improving inclusive education.

The first planned action was the creation of a network of centres with inclusive practices. 
The second step of this project involved conducting the seminars included within the Practicum III subject, of the specialization in Special Educational Needs in the Degree of Primary Education. This was done in conjunction with all the participating teaching staff from the two selected schools, the Practicum students and tutors of the Faculty.

Three joint seminars (under the form of discussion group) were held in the schools. At the request of the centres it was decided that all the participants would meet alternately in one of the two schools. The following is the calendar of the seminars together with the themes to be discussed:

\section{Table 2}

Seminar planning

\begin{tabular}{|c|c|c|c|}
\hline Seminar & Date & Plan & Place \\
\hline Seminar 1 & January 28, 2020 & $\begin{array}{l}\text { Sharing of the projects and } \\
\text { methodologies that each Practicum } \\
\text { tutor is implementing in their } \\
\text { classroom in both schools. }\end{array}$ & $\begin{array}{ll}\text { The La Paloma } \\
\text { Public School in } \\
\text { Azuqueca } & \text { de } \\
\text { Henares } & \\
\end{array}$ \\
\hline Seminar 2 & February 20, 2020 & $\begin{array}{l}\text { Students share their observations } \\
\text { and reflections on these projects } \\
\text { and methodologies that they have } \\
\text { observed in the classroom. } \\
\text { Proposals for improvement and } \\
\text { consequent actions. }\end{array}$ & $\begin{array}{l}\text { The San Sebastián } \\
\text { de Meco Public } \\
\text { School in Meco }\end{array}$ \\
\hline Seminar 3 & March 4, 2020 & $\begin{array}{l}\text { Analysis of the implemented actions } \\
\text { and their results. } \\
\text { Analysis and evaluation of the } \\
\text { project. }\end{array}$ & $\begin{array}{l}\text { Meeting } \\
\text { TEAMS }\end{array}$ \\
\hline
\end{tabular}

Teaching staff and directors of both schools, Practicum students and university teachers participated in these seminars. They were open, free and respectful spaces offering the possibility of presenting what each one did in their class. A debate was opened on the strengths of strategies and proposals for improvement were presented. In addition, there was a joint analysis process between the teacher and the Practicum student that helped both to improve the teaching process in the classroom.

In the first seminar participants presented distinct practices that were carried out in the different classes. In the second seminar, proposals for improvement and actions to be implemented in each classroom were established. The third seminar has seen the analysis of the results and actions to be maintained were concluded together with proposals for improvement. 


\section{Picture 1}

Seminar 2 on the February 20, 2020 in The San Sebastián de Meco Public school in Meco

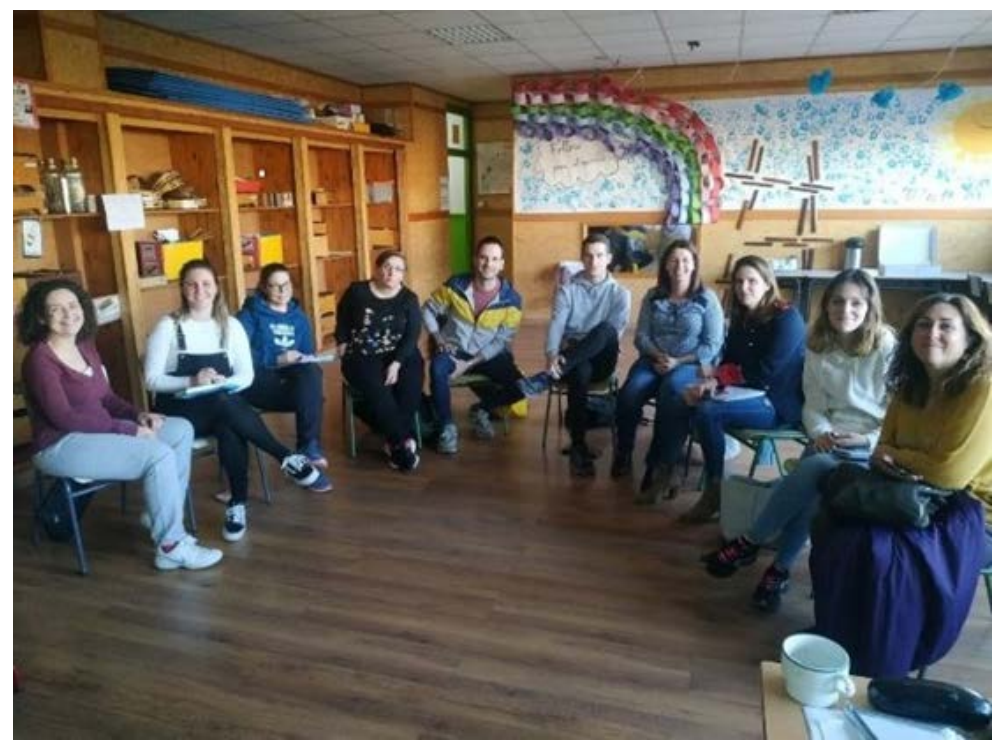

\section{Results}

In the analysis, four themes emerged that we will point out below, and through which we are going to show the results:

- $\quad$ Continuous training and initial training

- $\quad$ Teaching innovation

- $\quad$ Schools-University relationship

\section{Continuous training and initial training}

Regarding continuous training and initial training of teachers, it was observed that participation in the project improved pre-service teachers' methodology, innovation and understanding of inclusiveness as well as the performance by the teachers of the schools. The following responses from a primary school teacher were provided:

"It has allowed me to make a deeper reflection on my teaching practice, drawing both positive and negative conclusions and, of course, improvable, as well as knowing other ways and methods of work different from mine" (MPC1)

As seen, surveyed teachers also stated that participation in this project has allowed them to reflect on their own teaching practice.

Regarding initial training, the importance of the Practicum as a space for learning and reflection was clearly highlighted when theory and practice were combined. That was evidenced in the following responses from students who had participated in the 
project:

"It has helped me put into action what I have learned in a theoretical way in the degree. It has also made me see which ideas are easier to implement and greatly improve inclusion in the classroom. Furthermore, I believe that I have been able to contribute theoretical knowledge and ideas to improve the functioning of the groups with which I have worked" (APC1).

"I would highlight the participation with my tutor and the parallel class teacher. I believe that it is from them that I have truly been able to learn, I have observed each methodology used, they have allowed me to intervene in class, bring new things to propose to them every day, I have seen how their areas work together and how they asked me for my opinion within their projects" (APC2).

This Practicum has allowed students to understand that change is possible and is desirable:

"It is true that participating in this project has made me see that there are other people who consider how to change things just like me With it I have also been able to see how other schools manage day-to-day situations. But I would emphasize the participation with my tutor and the teacher of the paired class. I think it is from them that I have truly been able to learn, I have observed each methodology used, they have allowed me to intervene in class, bring new things to propose to them every day, I have seen how their areas work together and how they asked me for my opinion within their projects" (APC4).

\section{Teaching innovation for inclusive education}

Participating teachers emphasized that the development of this project had allowed them to implement proposals for improvement in the classroom as well as the inclusion of new techniques and methodologies. As evidenced in the following response from a Primary School teacher:

"It has given me a different and renewed point of view, providing new ideas and activities to apply in the classroom" (MPC2).

Innovation is not free from barriers and fears Haas, \& Arriagada (2018), even students themselves experience them, although it may seem that they, being in a period of training, are more open to the unknown, as shown in the following reflection:

"I think we need teachers today with the desire to go for it, the desire to learn, the desire to improve day by day and the desire to question everything, without accepting everything because someone says so. I undertook the experience with fear, since it was outside my comfort zone, but I can say that taking a risk to learn about what you like the most is the best you can do, I would repeat the experience without any doubt. An unforgettable experience to wrap up my last year" (APC4).

\section{Schools-University relationship}

One of the main objectives pursued by the project was improving the relationship between schools and the university, by creating collaborative networks. The participation in the joint seminars was beneficial and enriching for the participants and, in that sense, made possible to strengthen the School-University relationship. The 
development of these seminars in the schools highlighted the importance of sharing practices with the partner schools at the same educational level, even if they belong to a different autonomous community. As revealed in the following response from a primary school teacher from one of the centres:

"It has allowed me to know the educational response to the specific educational support needs of another centre" (MPC1).

Establishing of this collaborative network between the University and the schools has resulted in the schools themselves requesting the continuity of this way of working with students. Consequently, a new Innovation Project was solicited for the 2020/21 academic year and was carried out during the whole school year.

\section{Discussion}

Exchanging experiences is the best way to learn and reflect on one's teaching practice. There is the need of teachers willing to turn their teaching activity into a field of inquiry, reflection and collaboration, open to new professional space. Donal Shön (1992) considers that in a reflective practicum one learns to see the learning process as a practical work of modification, of change, of continuous reconstruction that has no end.

According to López and Romero (2004), the Practicum provides the student with an experience of great educational potential from which the knowledge and professional competence that are needed for the exercise of teaching can and should be built.

This study observed how the pre-service teachers' presence in the classroom allows experienced teachers to reflect on their own practice. As Haas, \& Arriagada (2018) states, we should not focus on the answers we are looking for, but on those questions that help us to reflect, question, debate, propose and improve. It is precisely in these joint reflection sessions where discussions happened about classroom practices and the way how to improve them from an inclusive perspective.

In addition, research focused on the evaluation of innovation projects has revealed the positive impact innovation has in schools, on teaching and on student learning. (Marcelo et al., 2011) and Chang (2005).

Our study shows results along the same lines as the study by Handscomb et al. (2014) regarding the increase of the aspirations and performance of schoolteachers by drawing on outside experience. Thus, developing and creating collaborative network of research schools, conducting complementary enriching activities and providing more access to resources and greater interaction between the university and the community creates opportunities for research. Through them, teachers and students can strive for an improvement in their personal and professional development, as well as increase in the collaboration of the school with the university.

In short, carrying out collaborative practices in which university lecturers, schoolteachers and university students participate, develops a greater sense of satisfaction and personal growth within the teaching staff and students. The practitioner teachers lose the safety of their office, they forget the usual routines of teachers in schools. This implies an openness and commitment to the students of the 
Practicum, directly affecting their level of utilization and satisfaction with the development of the Practicum (Higgins et al., 2013).

\section{Conclusions}

The current research evidenced that an inclusive Practicum in which university students feel to be at the same level as the rest of the members of the educational community tends to facilitate the relationship between schools and university and allows the integration of both theory and practice in the activities of pre-service teachers during their Practicum.

We have observed that this Practicum has been very enriching for both the university students and the teaching staff in the centres. The theory-practice/practicetheory conjunction has been revealed in classrooms as well as in work sessions. It has allowed the centres to change their view on the Practicum students and vice versa.

The creation of a network of schools with inclusive practices opens a very important avenue for collaboration, allowing to share experiences and facilitate not only teacher improvement but also the improvement of schools.

There was an enrichment of the school teaching staff due to the introduction of new methodologies and teaching acts proposed by the Practicum students. It also served to reflect on the schoolteachers' methodology evaluation. In turn, this led to the adoption of other methodologies which were also analysed in the common meetings. Additionally, new proposals for improvement appeared in and out of the school which were shared by the participating groups. In this way, the Practicum students brought new or updated with highly regarded contributions of which all members benefitted. Motivation and self-esteem were also one of the most valued assets of this project. Furthermore, students gained in developing a self-image as potential teachers which turned into a great personal satisfaction. It can be concluded that cooperation and the possibility of granting the pre-service teachers full responsibilities and certain independence is a crucial factor in training of new teachers who are destined to become excellent professionals.

\section{References}

Ainscow, M. (2001). Desarrollo de escuelas inclusivas. Ideas, propuestas y experiencias para mejorar las instituciones escolares. Narcea

Allen, J. M., \& Wright, S. E. (2014). Integrating theory and practice in the pre-service teacher education practicum. Teachers and Teaching: Theory and Practice, 20(2), 136-151. http://dx.doi.org/10.1080/13540602.2013.848568

Álvarez, C., \& Osoro, J. M. (2014). Colaboración Universidad-Escuela para el cambio escolar. Una investigación-acción en proceso. Innovación Educativa, 24, 215-227. https://doi.org/10.15304/ie.24.1483

Beck, C., \& Kosnik, C. (2002). Professors and the practicum: Involvement of university faculty in preservice practicum supervision. Journal of Teacher Education, 53(1), 6-19. https://search.proquest.com/scholarly-journals/professors-practicuminvolvement-university/docview/62296170/se-2?accountid=14609 
Blanco García, N. (2005). Innovar más allá de las reformas: Reconocer el saber de la escuela. REICE - Revista Electrónica Iberoamericana sobre Calidad, Eficacia y Cambio en Educación, 3 (1), 372-381.

Burns, R. W., Jacobs, J., \& Yendol-Hoppey, D. (2016). The changing nature of the role of the university supervisor and function of preservice teacher supervision in an era of clinically-rich practice. Action in Teacher Education, 38(4), 410-425. http://dx.doi.org/10.1080/01626620.2016.1226203

Chang, W. J. (2005). The rewards and challenges of teaching innovation in university physics: 4 years' reflection. International Journal of Science Education, 27(4), 407-425.

http://www.tandfonline.com/doi/pdf/10.1080/0950069042000323728

Conroy, P. W. (2014). Promoting reflective practices in special education through action research: Recommendations from preservice teachers. Networks: An Online Journal for Teacher Research, 16(2), 1-7. https://search.proquest.com/scholarly-journals/promoting-reflectivepractices-special-education/docview/1969020371/se-2?accountid=14609

Dewey, J. (1989). Art as Experience. In John Dewey: The Later Works, 1925-1953, Volume 10, edited by J. A. Boydston, pp. 1-352. Southern Illinois University Press. Echeita, G. (2008). "Inclusión y exclusión educativa”. "Voz y quebranto". REICE - Revista Electrónica Iberoamericana sobre Calidad, Eficacia y Cambio en Educación, 6(2), 9-18. https://www.redalyc.org/articulo.oa?id=55127024005

Elliot, J. (1991). Action research for educational change. Openup.

Esposito, G., Freda, M. F., \& Bosco, V. (2015). Examining perception of competency through practicum competencies outline. European Journal of Training and Development, 39(8), 700-720. http://dx.doi.org/10.1108/EJTD-05-2015-0037

Freire, P. (1990). La naturaleza política de la educación. Cultura, poder y liberación. Paidós.

García-Martínez, I., Pérez-Ferra, M., Jiménez, J., Ubago, L., \& Quijano-López, R. (2019). Promoting professional development for teachers through a scale of competence assessment. Research in Social Sciences and Technology, 4(2), 147-162. https://search.proquest.com/scholarly-journals/promoting-professionaldevelopment-teachers/docview/2488217318/se-2?accountid=14609

Grudnoff, L., Haigh, M., \& Mackisack, V. (2017). Re-envisaging and reinvigorating school-university practicum partnerships. Asia-Pacific Journal of Teacher $\begin{array}{lll}\text { Education, } & \text { 45(2), 180-193. }\end{array}$ http://dx.doi.org/10.1080/1359866X.2016.1201043

Guiney, M. C. (2018). Addressing problems of professional competence: Collaborating with university training programs to support struggling supervisees. Communique, 46(6), 3-4. https://search.proquest.com/scholarlyjournals/addressing-problems-professionalcompetence/docview/2034279764/se-2?accountid=14609

Han, S., Blank, J., \& Berson, I. R. (2020). Revisiting reflective practice in an era of teacher education reform: A self-study of an early childhood teacher education program. Journal of Early Childhood Teacher Education, 41(2), 162-182. http://dx.doi.org/10.1080/10901027.2019.1632993 
Haas, V., \& Arriagada, G. (2018). Reflexión, acción y crecimiento de los docentes en formación en las aulas de matemática. Transformación, 14(3), 297-309. http://scielo.sld.cu/scielo.php?script=sci arttext\&pid=S207729552018000300297\&lng=pt\&tlng $=$.

Handscomb, G., Gu, Q. y Varley, M. (2014). School-University Partnerships: Fulfilling the Potential. Literature Review. London Centre for Leadership in Learning, UCL Institute of Education. https://discovery.ucl.ac.uk/id/eprint/10065168

Higgins, A., Heinz, M., McCauley, V., \& Fleming, M. (2013). Creating the future of teacher education together: the role of emotionality in university-school partnership. Procedia - Social and Behavioral Sciences, 93, 1110-1115. 10.1016/ j.sbspro.2013.09.340

Huong, V. T. M., Tung, N. T. T., Hong, T. T. M., \& Hung, D. H. (2020). Partnerships between teacher education universities and schools in practicum to train pre-service teachers of Vietnam. International Journal of Higher Education, 9(5), 134-152. https://search.proquest.com/scholarly-journals/partnerships-betweenteacher-education/docview/2488224392/se-2?accountid=14609

Illin, G. (2020). Reflection or description: A document analysis on ELT student teachers' reflective journals. Journal of Language and Linguistic Studies, 16(2), 1019-1031. https://search.proquest.com/scholarly-journals/reflection-descriptiondocument-analysis-on-elt/docview/2458993513/se-2?accountid=14609

Kasula, A. (2015). Conducting action research in a practicum: A student teacher's $\begin{array}{llll}\text { perspective. CATESOL 229-237. } & \text { Journal, }\end{array}$ https://search.proquest.com/scholarly-journals/conducting-action-researchpracticum-student/docview/1871586293/se-2?accountid=14609

Kemmis, S., \& Mctaggart, R. (1988). Cómo planificar la investigación-acción. Laertes.

Knapczyk, D. R., Hew, K. F., Frey, T. J., \& Wall-Marencik, W. (2005). Evaluation of online mentoring of practicum for limited licensed teachers. Teacher Education and Special Education, 28(3-4), 207-220. https://search.proquest.com/scholarlyjournals/evaluation-online-mentoring-practicumlimited/docview/62140175/se-2?accountid=14609

Köksal, D., \& Genç, G. (2019). Learning while teaching: Student teachers' reflections on their teaching practicum. Journal of Language and Linguistic Studies, 15(3), 895913. https://search.proquest.com/scholarly-journals/learning-while-teachingstudent-teachers/docview/2461135146/se-2?accountid=14609

López Melero, M. (2004). Construyendo una escuela sin exclusiones. Una forma de trabajar con proyectos en el aula. Aljibe.

López, M. C., \& Romero, M. A. (2004). El sentido del prácticum en la formación demaestros. III Congreso Internacional "Docencia Universitaria e Innovación”, Gerona, 30 junio - 2 julio.

Lupart, J., \& Webber, C. (2012). Canadian schools in transition: Moving from dual education systems to inclusive schools. Exceptionality Education International, 22(2), 8-37. https://search.proquest.com/scholarly-journals/canadian-schoolstransition-moving-dual-education/docview/1347460736/se2?accountid=14609

Magumise, J., \& Sefotho, M. M. (2020). Parent and teacher perceptions of inclusive 
education in Zimbabwe. International Journal of Inclusive Education, 24(5), 544560. http://dx.doi.org/10.1080/13603116.2018.1468497

Marcelo, C., Mayor, C. \& Gallego, B. (2011). Evaluación de la innovación educativa. In C. Marcelo (Coord.). Evaluación del desarrollo profesional docente (129-150). Editorial Davinci.

Mauri, T., Onrubia, J., Colomina, R., \& Clarà, M. (2019). Sharing initial teacher education between school and university: Participants' perceptions of their roles and learning. Teachers and Teaching: Theory and Practice, 25(4), 469-485. http://dx.doi.org/10.1080/13540602.2019.1601076

Méndez, P., \& Pérez, F. (2017). Understanding student-teachers' performances within an inquiry-based practicum. English Language Teaching, 10(4), 127-139. https://search.proquest.com/scholarly-journals/understanding-studentteachers-performances/docview/1913352164/se-2?accountid=14609

Mérida, R., González, E. \& Olivares, M.A. (2012). Redes de aprendizaje escuelas infantiles-universidad. Evaluación de una experiencia de innovación. Cultura y Educación: revista de teoría, investigación y práctica, 24 (1), 95-110. https://doi.org/10.1174/113564012799740849

Mérida, R. (2001). El Prácticum: un complejo espacio de formación. En L. Iglesias, M. Zabalza, A. Cid \& M. Raposo (coords.). Desarrollo de Competencias Personales y Profesionales en el Prácticum. VI Symposium Internacional sobre el Prácticum. Lugo: Unicopia.

Mukeredzi, T. G. (2015). Creating space for pre-service teacher professional development during practicum: A teacher educator's self-study. Australian Journal of Teacher Education, 40(2), 1-21. https://search.proquest.com/scholarly-journals/creating-space-pre-serviceteacher-professional/docview/1697506361/se-2?accountid=14609

Nguyen, M. H. (2017). Negotiating contradictions in developing teacher identity during the EAL practicum in Australia. Asia-Pacific Journal of Teacher Education, 45(4), 399-415. http://dx.doi.org/10.1080/1359866X.2017.1295132

Parr, G., \& Chan, J. (2015). Identity work in a dialogic international teaching practicum. Teaching Education, 26(1), 38-54. http://dx.doi.org/10.1080/10476210.2014.997701

Pérez, S. (2012). Revisión, clasificación y propuestas de mejora del prácticum en educación musical. Profesorado. Revista de Currículum y Formación del Profesorado, 16 (1), 345-359. http://www.ugr.es/ recfpro/rev161COL8.pdf

Pérez, M. P., \& Gallego, M. J. (2004). La enseñanza práctica en las titulaciones de maestro especialista de Educación Infantil y de Educación Musical. Actas del III Congreso Internacional «Docencia Universitaria e Innovación». Gerona: Universidad de Gerona.

Prabjandee, D. (2019). Becoming English teachers in Thailand: Student teacher identity development during teaching practicum. Issues in Educational Research, 29(4), 1277-1294. $\quad$ https://search.proquest.com/scholarly-journals/becomingenglish-teachers-thailand-student/docview/2461125257/se2?accountid=14609

Ragawanti, D. T. (2015). Cultivating pre-service teachers' classroom management skills 
through teaching practicum: A reflective practice. TEFLIN Journal: A Publication on the Teaching and Learning of English,26(1), 117-128. https://search.proquest.com/scholarly-journals/cultivating-pre-serviceteachers-classroom/docview/1895988962/se-2?accountid=14609

Robinson, D. B., \& Walters, W. (2016). Exploring other practicum possibilities: An action research initiative. Canadian Journal of Action Research, 17(3), 39-56. https://search.proquest.com/scholarly-journals/exploring-other-practicumpossibilities-action/docview/1895970524/se-2?accountid=14609

Ruiz Bernardo, P., Sánchez-Tarazaga, L., \& Mateu-Pérez, R. (2018). La innovación pedagógica de la mano de la investigación---acción para mejorar la calidad de las prácticas externas de los Grados de Maestro/a en Educación Primaria y Educación Infantil. Revista Electrónica Interuniversitaria de Formación del Profesorado, 21(1), 33-49.http://dx.doi.org/10.6018/reifop.21.1.277681

Sales, A., Moliner, O., \& Traver, J. A. (Eds.) (2010). La construcción de la escuela intercultural inclusiva desde procesos de investigación-acción. Servicio de Publicaciones de la Universitat Jaume I.

Schuijers, J. A., McDonald, S. J., Julien, B. L., Lexis, L. A., Thomas, C. J., Chan, S., \& Samiric, T. (2013). The effectiveness of separating theory and practicum as a conduit to learning physiology. Advances in Physiology Education, 37(2), 153-156. http://dx.doi.org/10.1152/advan.00161.2012

Schon, A. (1987). Educating the reflective practitioner: Toward a new design for teaching and learning in the professions. Jossey-Bass.

Seban, D. (2015). Development of preservice identities: Learning from a multigrade classroom practicum context. Journal of Education for Teaching: International Research and Pedagogy, 41(1), 19-36. http://dx.doi.org/10.1080/02607476.2014.992632

Sim, C. (2010). Sustaining Productive Collaboration Between Faculties and Schools. Australian Journal of Teacher Education, 35(5). http://dx.doi.org/10.14221/ajte.2010v35n5.2

Smith, K., \& Lev-Ari, L. (2005). The place of the practicum in pre-service teacher education: the voice of the students. Asia-Pacific Journal of Teacher Education, 33 (3), 289-302. https://doi.org/10.1080/13598660500286333

Stenberg, K., Rajala, A., \& Hilppo, J. (2016). Fostering theory-practice reflection in teaching practicums. Asia-Pacific Journal of Teacher Education, 44(5), 470-485. http://dx.doi.org/10.1080/1359866X.2015.1136406

Tan, Y. S. M., Amiel, J. J., \& Cheng, C. (2020). Theorizing variation theory--A case of collaborative action research involving science teacher candidates. Educational Action Research, 28(3),

443-461.

http://dx.doi.org/10.1080/09650792.2019.1575257

Tiainen, O., Korkeamäki, R., \& Dreher, M. J. (2018). Becoming reflective practitioners: A case study of three beginning pre-service teachers. Scandinavian Journal of Educational Research, 62(4), 586-600. http://dx.doi.org/10.1080/00313831.2016.1258673

Trent, J. (2013). From learner to teacher: Practice, language, and identity in a teaching practicum. Asia-Pacific Journal of Teacher Education,41(4), 426-440. 


\section{http://dx.doi.org/10.1080/1359866X.2013.838621}

Trent, J. (2018). 'Fitting in' or 'being different'? integration, separation, and identity construction during a teaching practicum in Hong Kong. Teacher Development, 22(4), 571-586. http://dx.doi.org/10.1080/13664530.2018.1466722

Turunen, T. A., \& Tuovila, S. (2012). Mind the gap. Combining theory and practice in a field experience. Teaching Education, 23(2), 115-130. http://dx.doi.org/10.1080/10476210.2012.669751

Ulvik, M. (2014). Student-teachers doing action research in their practicum: Why and how? Educational Action Research, 22(4), 518-533. http://dx.doi.org/10.1080/09650792.2014.918901

Ulvik, M., Helleve, I., \& Smith, K. (2018). What and how student teachers learn during their practicum as a foundation for further professional development. Professional Development in Education, 44(5), 638-649. http://dx.doi.org/10.1080/19415257.2017.1388271

Ulvik, M., Riese, H., \& Roness, D. (2018). Action research--connecting practice and theory. Educational Action Research, 26(2), 273-287. http://dx.doi.org/10.1080/09650792.2017.1323657

Villa, A., \& Poblete, M. (2004). Practicum y evaluación de competencias. Profesorado. Revista de Currículum y Formación del Profesorado, 8 (2), 1-19. http://www.ugr.es/ recfpro/rev82ART2.pdf

Widdall, V., Lachance, A., \& Livermore, J. (2019). Learning while building: Enhancing opportunities for teacher candidate development within professional development schools through programmatic analysis. Journal of Inquiry and Action in Education, 10(2), 72-89. https://search.proquest.com/scholarlyjournals/learning-while-building-enhancingopportunities/docview/2396834888/se-2?accountid=14609

Williams, J. (2014). Teacher educator professional learning in the third space: Implications for identity and practice. Journal of Teacher Education, 65(4), 315326. http://dx.doi.org/10.1177/0022487114533128

Yuan, R., Liu, W., \& Lee, I. (2019). Confrontation, negotiation and agency: Exploring the inner dynamics of student teacher identity transformation during teaching practicum. Teachers and Teaching: Theory and Practice, 25(8), 972-993. http://dx.doi.org/10.1080/13540602.2019.1688286

Zabalza, M. A. (2003). Competencias docentes del profesorado universitario. Calidad y desarrollo profesional. Narcea.

Zhu, G. (2017). Chinese student teachers' perspectives on becoming a teacher in the practicum: Emotional and ethical dimensions of identity shaping. Journal of Education for Teaching: International Research and Pedagogy, 43(4), 491-495. http://dx.doi.org/10.1080/02607476.2017.1341162 


\section{Appendix}

\section{Cuestionario para estudiantes:}

1. La participación en este proyecto, me ha permitido mejorar la formación inicial respecto a metodología, innovación y escuela inclusiva recibida en las asignaturas de grado.

Totalmente de acuerdo De acuerdo Indiferente En desacuerdo Totalmente en desacuerdo

2. La participación en el proyecto me ha hecho reflexionar sobre la práctica docente.

Totalmente de acuerdo De acuerdo Indiferente En desacuerdo Totalmente en desacuerdo

3. La participación en este proyecto, me ha permitido colaborar con el tutor para poner en marcha propuestas de mejora en el aula.

Totalmente de acuerdo De acuerdo Indiferente En desacuerdo Totalmente en desacuerdo

4. Los conocimientos teóricos y la experiencia docente del tutor me han permitido conocer nuevas técnicas y nuevas metodologías.

Totalmente de acuerdo De acuerdo Indiferente En desacuerdo Totalmente en desacuerdo

5. Considero que ha sido beneficioso compartir buenas prácticas con otro centro docente.

Totalmente de acuerdo De acuerdo Indiferente En desacuerdo Totalmente en desacuerdo

6. Considero que este proyecto ha favorecido la mejora de la relación EscuelaUniversidad

Totalmente de acuerdo De acuerdo Indiferente En desacuerdo Totalmente en desacuerdo

7. Considero que ha sido enriquecedor llevar a cabo seminarios conjuntos alumnos de la universidad y maestros de los centros de prácticas.

Totalmente de acuerdo De acuerdo Indiferente En desacuerdo Totalmente en desacuerdo

8. Considero adecuada la realización del seminario on-line en vez del seminario presencial, como forma de responder a las restricciones durante el confinamiento a causa de la situación producida por el Covid-19.

Totalmente de acuerdo De acuerdo Indiferente En desacuerdo Totalmente en desacuerdo

9. Finalmente podrías indicar con tus propias palabras ¿Qué te ha aportado este prácticum y tu participación en el proyecto? 


\section{Cuestionario para profesores tutores de los colegios:}

1. La participación en este proyecto, me ha permitido mejorar mi formación continua respecto a metodología, innovación y escuela inclusiva.

Totalmente de acuerdo De acuerdo Indiferente En desacuerdo Totalmente en desacuerdo

2. La participación en el proyecto te han hecho reflexionar sobre la práctica docente.

Totalmente de acuerdo De acuerdo Indiferente En desacuerdo Totalmente en desacuerdo

3. La participación en este proyecto, me ha permitido poner en marcha propuestas de mejora en el aula.

Totalmente de acuerdo De acuerdo Indiferente En desacuerdo Totalmente en desacuerdo

4. Los conocimientos teóricos de los alumnos de prácticas y su participación en el aula me han permitido implantar nuevas técnicas y nuevas metodologías en el aula.

Totalmente de acuerdo De acuerdo Indiferente En desacuerdo Totalmente en desacuerdo

5. Considero que ha sido beneficioso compartir buenas prácticas con otro centro docente.

Totalmente de acuerdo De acuerdo Indiferente En desacuerdo Totalmente en desacuerdo

6. Considero que este proyecto ha favorecido la mejora de la relación EscuelaUniversidad.

Totalmente de acuerdo De acuerdo Indiferente En desacuerdo Totalmente en desacuerdo

7. Considero que ha sido enriquecedor llevar a cabo seminarios conjuntos alumnos de la universidad y maestros de los centros de prácticas.

Totalmente de acuerdo De acuerdo Indiferente En desacuerdo Totalmente en desacuerdo

8. Considero adecuada la realización del seminario on-line en vez del seminario presencial, como forma de responder a las restricciones durante el confinamiento a causa de la situación producida por el Covid-19.

Totalmente de acuerdo De acuerdo Indiferente En desacuerdo Totalmente en desacuerdo

9. Finalmente podrías indicar con tus propias palabras ¿Qué te ha aportado este prácticum y tu participación en el proyecto? 